\title{
A filosofia e os seus cães: dos cínicos à canalha
}

\author{
La philosophie et ses chiens: des cyniques à la canaille
}

\section{Diogo Sardinha}

Pós-doutorando da Universidade de Paris 1 (NoSoPhi), Paris - França, e-mail : diogo_pt@hotmail.com

\section{Resumo}

Ao longo de sua história, a filosofia se mostrou sobejamente avessa à insolência e à selvajaria. No entanto, quem determina as fronteiras desses espaços, as linhas para lá das quais uma conduta se torna intolerável? Na sua antropologia, típica do século das luzes, Kant critica o que considera ser o caráter selvagem da populaça. Para ilustrar o que pretende dizer, ele recorre à expressão francesa canaille du peuple. Bem mais próximo de nós, Foucault se interessa pela figura antiga do filósofo cínico, que ele apresenta como um insolente à vista dos códigos da cidade, a qual acaba por excluí-lo. Ora, a raiz etimológica de canaille e de cínico é a mesma: o cão. A partir daqui, várias perguntas se insinuam: que relação existe entre a canalha, isto é, os cães do povo; e os cínicos, cães da filosofia? Se o cínico é filósofo, significa que a animalidade é interior à filosofia? As respostas a essas interrogações se tornam mais difíceis quando se compreende que as tensões entre seus elementos são mais complexas do que se julgava.

Palavras-chave: Kant. Foucault. Antropologia. Povo. Cínicos. 


\section{Résumé}

Au fil de son histoire, la philosophie s'est souvent montrée hostile à l'insolence et à la sauvagerie. Mais qui détermine les frontières au-delà desquelles un comportement devient intolérable? Dans son anthropologie, typique des Lumières, Kant fustige ce qu'il considère comme le caractère sauvage de la populace. Pour éclaircir son raisonnement, il se sert du mot français «la canaille du peuple». Plus récemment, Foucault s'est intéressé à la figure antique do philosophe cynique, qu'il présente comme un insolent au regard des codes de la cité, laquelle finit par l'exclure. Or, la racine étymologique de canaille et de cynique est la même: le chien. De là, différentes questions transportent la pensée: quel rapport existe-t-il entre la canaille, c'est-à-dire les chiens du peuple, et les cyniques, les chiens de la philosophie ? Si le cynique est un philosophe, cela signifie-t-il que l'animalité est intérieure à la philosophie? Les réponses à ces interrogations deviennent plus difficiles dès qu'on comprend que les tensions entre leurs éléments sont plus complexes qu'on ne le croyait.

Mots-clefs: Kant. Foucault. Anthropologie. Peuple. Cyniques.

\section{0 cínico, filósofo-cão intolerável}

Todo leitor do derradeiro curso de Foucault no Colégio de França, intitulado A coragem da verdade: o governo de si e dos outros II, reconhecerá que esse volume aborda um só assunto principal - a parrhesia. Contudo, ele o faz em duas partes, que, embora de igual extensão, são muito claramente distintas: a primeira vai, sensivelmente, do início até o meio do livro (mais ou menos até a página 150) e trata do tema, recorrendo sobretudo à figura de Sócrates. A segunda parte centra-se na tradição cínica. Deixando de lado a primeira, gostaria de começar por um florilégio de passagens nas quais são apresentados alguns traços do cinismo. Veremos mais adiante o porquê dessa escolha.

Começo pela justificação que oferece Foucault para dar tanto relevo a essa escola em particular:

Parece-me que no cinismo, na prática cínica, a exigência de uma forma de vida extremamente tipificada - com regras, condições ou modos 
muito caracterizados, muito bem definidos - se articula muito fortemente com o princípio do dizer-verdadeiro sem vergonha e sem receio, do dizer-verdadeiro ilimitado e corajoso, do dizer-verdadeiro que extrema sua coragem e ousadia até transformar-se em insolência intolerável (FOUCAULT, 2009, p. 152-153).

Cabe ressaltar, nestas linhas, a íntima associação em que se encontram três ideias importantes: o cinismo, o dizer-verdadeiro e a insolência intolerável. A forma cínica de dizer a verdade é inadmissível. Por enquanto, ainda não sabemos que não é apenas a forma de dizer a verdade, mas que é a própria verdade, na sua crueza, que é inaceitável. Essas palavras também nada nos ensinam sobre para quem ela é intolerável: de fato, qual o público que não suporta nem escutar, nem ver a verdade que os cínicos dizem e mostram? Para quem os cínicos são insolentes-que-não-admitem-qualquer-tolerância? Se a parrhesia em geral é incômoda, perturbadora, aqui ela o é em excesso: é por esse excesso que os cínicos atraem a atenção de Foucault.

Esse excesso intolerável será importante no decurso da minha leitura, na medida em que ele implica uma dupla referência ao exterior, primeiro pela dimensão de transbordo que comporta a mensagem excessiva; e, segundo, pela intenção, talvez mesmo pela necessidade de banir, de expulsar o que é demasiado, o que não cabe dentro dos limites do tolerável. Se algo é considerado por alguém como intoleravelmente insolente, isso significa que há um limite da tolerância que esse mesmo alguém determina (a menos que seja o inverso, e que o limite determine alguém como tolerante ou intolerante). Mais ainda, parece ser o cínico que procura o limite, extremando para isso sua posição, radicalizando seu discurso: nesse caso seria de sua inteira responsabilidade se ele acaba se encontrando para lá do limite - ele coloca-se além dos limites e pronuncia, desse modo, o seu próprio banimento. Melhor: em vez de ser banido por outrem, é ele que se exila. Em todo o caso, está claramente presente uma linha de demarcação, uma fronteira e os espaços correspondentes aos dois lados da fronteira: um fora e um dentro do tolerável ou do socialmente aceitável. 
Vamos agora ao que Foucault designa como a «prática cínica, a exigência de uma forma de vida extremamente tipificada - com regras, condições ou modos muito caracterizados, muito bem definidos». Para isso, detenhamo-nos na descrição seguinte:

o cínico é o homem do cajado [...], o homem de sandálias ou descalço, é o homem de barba hirsuta, é o homem sujo. É o homem também que erra, é o homem ao qual falta toda a inserção, ele não tem nem casa, nem família, nem lar, nem pátria [...], é o homem da mendicidade também (FOUCAULT, 2009, p. 157).

Já pela sua apresentação, pelo seu aspecto físico, a sua presença é dificilmente aceitável. Socialmente, ele não obedece às convenções vestimentárias nem de higiene. Familiarmente, não tem integração na estrutura doméstica. Politicamente, não tem ligação com a cidade. Economicamente, deserta os princípios da produção. Dele nem pode dizer-se sequer com propriedade que é um estrangeiro na sua própria terra, pois precisamente ele não tem terra. A sua figura transporta um vazio perturbador, na medida em que revela como toda ou quase toda a organização da vida em comum pode ser dispensada. Pelo menos, ele lança a dúvida sobre a necessidade de os seres humanos viverem enquadrados pelas grelhas sociais que eles próprios inventaram. Contudo, se não é por necessidade que vivem assim, por que é então? Deixemos por ora essa pergunta em suspenso.

Foucault recorda como, na Antiguidade, coexistem descrições ora elogiosas ora críticas do personagem cínico. Por exemplo, figura importante para Sêneca, Demétrio era «um homem ligado à aristocracia romana, que foi conselheiro» de altos dignitários do Império (FOUCAULT, 2009, p. 180). Em contrapartida, note-se esta descrição oposta:

No outro extremo, o cinismo pode ser simbolizado por um personagem como Peregrino [...]. Ele é, exatamente ao contrário, um vagabundo, um vagabundo ostentoso que esteve quase certamente ligado aos movimentos populares e anti-romanos de Alexandria, dirigindo, em Roma, o seu ensino aos idiotai (aqueles que não têm nem cultura, nem estatuto social ou político). Acaba sendo expulso de Roma (FOUCAULT, 2009, p. 180-181). 
Mais uma vez, o espaço ocupado pelo cínico é instável: Roma expulsa-o, ei-lo do outro lado da fronteira que circunda a cidade. Mas o importante nas linhas que acabo de citar é a proximidade em que ele se encontra do povo, sublinhando nessa palavra não o conjunto dos cidadãos cultos, mas a plebe ignara. Vagabundo, ele se aproxima daqueles que são, em um sentido que teremos ainda de clarificar, seus iguais. O filósofo está no meio do povo, da arraia-miúda, mas ele está ainda mais entre aqueles que se revoltam, que se sublevam, as gentes dos «movimentos populares e antirromanos». Esse cínico é o filósofo da plebe em movimento. Não é, por isso, de estranhar que Roma o proscreva. Foucault prossegue:

ao cínico se lhe aponta sua grosseria, sua ignorância, sua incultura. Eis como exemplo, no final do século II, [o retrato que] Luciano - grande adversário evidentemente da filosofia em geral e do cinismo em particular - traça do cínico. É num diálogo chamado Os Fugitivos, no qual é a Filosofia que fala.

[...] No parágrafo 12 dos Fugitivos, ela diz o seguinte: "Existe uma espécie de homens desprezíveis, na sua maior parte servis e mercenários, que, entregues desde a infância a trabalhos grosseiros, não puderam estabelecer comigo ligação alguma; eles se debatem com a escravatura, ocupados a ganhar seus salários, e exercendo os mesteres apropriados à sua condição, sapateiros, marceneiros [...], cardadores de lã. [...] Este texto é interessante por toda a paisagem social [...] na qual o cinismo é percebido (FOUCAULT, 2009, p. 182).

A paisagem social a que Foucault alude é a do trabalho, atividade desvalorizada. O cínico é apresentado como saindo desse mundo da quase escravatura, em todo o caso de uma dependência econômica de labores indignos, para um cidadão de pleno direito e, por razão Não poderia faltar a dimensão etimológica dessa tradição, com uma variante menor, mas ainda assim curiosa, no seu interior:

a respeito das razões pelas quais Diógenes tinha sido chamado "cão" há diferentes interpretações. Umas são de ordem local: seria por causa do lugar que Diógenes [na realidade: Antisteno, o primeiro cínico] teria escolhido como domicílio [o ginásio de Cinosarga]. De acordo com outras 
interpretações, foi porque efetivamente ele teria levado uma vida de cão. Apodado pelos outros de cão, ele teria tomado por sua conta este epíteto e ter-se-ia proclamado cão (FOUCAULT, 2009, p. 224).

Comentadores do século I da nossa era explicam esse nome da seguinte forma:

Primeiro, a vida kunikos é uma vida de cão por ser sem pudor, sem vergonha, sem respeito humano. É uma vida que faz em público e à vista de todos o que apenas os cães e os animais ousam fazer, ao passo que os homens normalmente o escondem. [...] Segundo, a vida cínica é uma vida de cão porque, como a dos cães, ela é indiferente. Indiferente a tudo o que pode acontecer, ela não se prende a nada, se contenta com o que tem, ela conhece apenas as necessidades que pode satisfazer imediatamente. Terceiro, a vida dos cínicos é uma vida de cão [...] por que é de alguma forma uma vida que ladra [...], uma vida capaz de bater-se, de ladrar contra os inimigos, que sabe distinguir os bons dos maus, os verdadeiros dos falsos [...]. Enfim, quarto, a vida cínica é [...] uma vida de cão de guarda, uma vida que sabe dedicar-se para salvar os outros e proteger a vida dos donos (FOUCAULT, 2009, p. 224).

Com a designação de cão, entra em cena a animalidade. Tal como o trabalho manual quase equiparado à escravatura, também a animalidade é usada para desqualificar o cinismo. O que não pode ser tolerado, quando não é posto de fato fora da cidade, é pelo menos banido de direito do gênero humano. A animalidade é, pois, um valor negativo para a moral comum, animalidade que, no entanto, a filosofia cínica saberá transmudar em valor positivo, apresentando-a como um exercício e, desse ponto de vista, um dever. Mas vejamos como a animalidade é normalmente encarada:

o que resulta [do] princípio de uma vida reta que deve ser indexada à natureza, e só à natureza, é [para os cínicos] a valorização positiva da animalidade. E isto é mais uma vez algo de singular e escandaloso no pensamento antigo. Pode dizer-se que, de forma geral, e resumindo muito, a animalidade desempenhava, no pensamento antigo, o papel de ponto de diferenciação absoluta para o ser humano. Era distinguindo-se da animalidade que o ser humano afirmava e manifestava a sua 
humanidade. A animalidade era sempre, mais ou menos, um ponto de repulsão para esta constituição do homem como ser razoável e humano (FOUCAULT, 2009, p. 244).

Gostaria de terminar esta recolha de citações, que pode parecer bastante aleatória, mas cujo propósito tornar-se-á claro mais adiante, com uma referência ao que Foucault formula nos termos de um paradoxo. Por um lado, o cinismo é duramente criticado; por outro, essa censura é quase sempre feita por seus inimigos em nome (explica Foucault) do que eles consideram um outro cinismo, o verdadeiro, o bom, o original, o de Diógenes, e um mais antigo ainda, como se a vida cínica fosse um elemento primordial da humanidade. Como declara Foucault:

ao mesmo tempo e diante deste cinismo ostensivo, barulhento, agressivo, que nega as leis, as tradições e as regras, mesmo seus adversários mais acintosos fazem sempre valer o valor e os méritos de um outro cinismo, um outro cinismo que é ou seria comedido, refletido, educado, discreto, honesto e realmente austero (FOUCAULT, 2009, p. 183).

Dito isso, vamos então ao paradoxo:

mas vocês veem que há aqui um paradoxo muito curioso, porque, por um lado, vimos o cinismo descrito como uma forma de existência muito particular, à margem das instituições, das leis, dos grupos sociais mais reconhecidos: o cínico é alguém que está verdadeiramente à margem da sociedade e circula em torno da própria sociedade, sem que ela possa aceitar recebê-lo. O cínico é enxotado, o cínico é errante. E, ao mesmo tempo, o cínico aparece como o núcleo universal da filosofia. O cinismo está no âmago da filosofia e o cínico gira em torno da sociedade sem ser nela admitido. Paradoxo interessante (FOUCAULT, 2009, p. 186-187).

Com essa citação termino minhas referências às indicações de Foucault. Resumindo este breve percurso, vale sublinhar que Foucault se interessa pela tradição cínica a propósito da parrhesia, mas que rapidamente deriva para duas outras vias simultâneas. A primeira é a da vida reta tal como é concebida nessa tradição, sobretudo nos primeiros séculos da nossa era, porém, com referências constantes a seus 
fundadores. A segunda via é a das reações que o comportamento e o estilo de vida dos cínicos, que vão muito além da parrhesia propriamente dita, desencadeiam nas outras pessoas. Podemos sintetizar as ideias apuradas em quatro pontos:

1) por um lado, o cínico é intolerável para os cidadãos, conjuntamente na medida em que a vileza do seu aspeto sujo e miserável causa repugnância, na medida também em que a grosseria de seus modos o torna desprezível e, ainda, na medida em que seu discurso agressivo nega as leis, as tradições e as regras;

2) por outro lado (ou melhor: em contrapartida), ele é não apenas tolerável para a plebe, mas é também próximo dela, tanto quando ele lhe comunica seus ensinamentos como quando a acompanha na revolta e talvez mesmo quando a incita à revolta;

3) por outro lado, ainda, ele traz consigo um paradoxo, porquanto ele é um fora da lei e um fora-dos-laços-sociais-e-políticos, encontrando-se, desse ponto de vista, à margem da sociedade e, ao mesmo tempo, pertencendo ao espaço da cidade pelo seu estilo escandaloso e barulhento, de tal modo que a cidade pode mesmo dar-lhe ordem de expulsão;

4) enfim, quando não o expulsa, a cidade (isto é, os cidadãos e suas instituições) desqualifica-o, chamando-o de cão e tratando-o como tal, e vendo nele a animalidade que ela pretende banir em proveito da humanidade.

Em suma, a partir da figura do filósofo-cão são esses os aspectos escandalosos e subversivos que eu gostaria de pôr em relevo, com as diferentes reações que eles suscitam, dependendo da parte da cidade que os observa, ora os cidadãos, ora a plebe.

\section{A canalha do povo}

O que me interessa na leitura foucaultiana não é, antes de mais nada, o que ela nos ensina a respeito do que terá sido a vida ética dos 
cínicos. Efetivamente, podemos imaginar que essa leitura seja depreciada em vários detalhes pelos filólogos e historiadores, especialistas da Antiguidade e do cinismo. O mais importante para mim (embora esses temas estejam estreitamente associados) foi a visão que, segundo o esquema de inteligibilidade foucaultiano, a sociedade tem dos cínicos, e os modos por via dos quais essa última constrói tal visão e em seguida a integra.

Emprego o verbo integrar com um conjunto de acepções, entre elas a do destino que a sociedade dá à dita visão que ela mesma construiu do cínico, a de como se relaciona com essa visão enquanto representação, de como se relaciona com a pessoa assim representada (por exemplo, expulsando-o ou então tolerando-o), e de como se define a si mesma a partir desse retrato que traça de um outrem interior, nome por meio do qual remeto para o paradoxo da presença cínica, presença que está ao mesmo tempo dentro da cidade e fora das estruturas que atravessam a cidade e a determinam em uma certa constância.

O que chamou minha atenção para o cinismo - e a forma como ele não apenas diz uma verdade, mas ainda espelha ou manifesta uma verdade, ou ainda a forma como o retrato do cínico revela informações consideráveis (isto é, verdades) sobre o que é a sociedade; sobre como ela se constrói, se mantém no tempo e no espaço, define seus inimigos (pelo menos seus adversários) e se define por confrontação com eles; sobre como ela localiza perigos ou investe certas partes de si mesma considerando-as perigosas -, o que cativou minha atenção foi o parentesco, a semelhança entre o cinismo assim descrito e outra experiência filosófica, ligada não à figura do cínico, mas à da canalha.

O primeiro elemento, e o mais evidente, que o cínico e a canalha têm em comum é que ambos partilham o que chamarei de canidade, isto é, ambos são humanos caninos, seres humanos com estatuto (ou reduzidos ao estatuto) de cães. Cínico e canalha têm na verdade a mesma origem etimológica, aquele por via do grego kuon, essa por via do latim canis. Esse paradigma animalesco atravessa a história da filosofia, cujos cães são os cínicos. Mas ele é também uma referência na concepção da organização social, cuja parte animalesca é (em todo o caso foi) precisamente encarnada pela canalha. Para entendermos melhor o que estou 
querendo dizer, leia-se essa nota extraída da Antropologia de um ponto de vista pragmático, de Kant: "o nome injurioso la canaille du peuple tem provavelmente sua origem em canalicola, um bando de ociosos que andava de lá para lá junto ao canal na antiga Roma e que ridicularizavam as pessoas ocupadas (KANT, 1798, p. 311, nota*, trad., p. 206).

Sucede, com essa filiação etimológica, algo parecido com a incerteza sobre os motivos pelos quais os primeiros cínicos teriam sido chamados «cães»: se pelo nome do local onde se reuniam ou se pela vida que levavam. Segundo Kant e outros autores precedentes, canalha viria da designação dada a esse canal em Roma. Ora, o editor científico da Antropologia nas Obras completas de Kant explica, no final da edição crítica, que essa derivação é errada e que canalha provém de canis. Em todo o caso, o recurso de Kant àquilo a que ele chama de «nome injurioso» tem um valor capital, ao desenhar um retrato fulgurante da vida social, mais ou menos do mesmo jeito que a passagem dos Fugitivos, de Luciano, em que a filosofia fala dos trabalhadores manuais cuja vida se aparenta à dos escravos, é qualificada por Foucault como "interessante por toda a paisagem social [...] na qual o cinismo é percebido" (FOUCAULT, 2009, p. 182).

Na imagem da canalha do povo observamos sobre a mesma via da metrópole, passando junto uns dos outros e cruzando-se, dois mundos que a um tempo se misturam e não se confundem. De um lado, os cidadãos que se consagram aos seus afazeres ocupam-se, pelas suas atividades, do bem-estar e da prosperidade da cidade. Do outro lado, desocupados deambulam, tentando a todo o custo infiltrar sua desordem no tecido uniforme de colectividade e suscitando, por isso, o desprezo e a censura. Resta explicar que a nota de Kant é um aparte (não sem relevância) a uma passagem do texto principal que toca a própria definição da sociedade política. Esse trecho diz o seguinte:

pela palavra povo (populus) se entende a porção de seres humanos unidos num território, desde que constitua um todo. Aquela porção ou também parte deles que se reconhece unida, pela procedência comum, num todo civil, chama-se nação (gens); a parte que se exclui dessas leis (a porção selvagem nesse povo) se chama plebe (vulgus), cujo vínculo ilegal 
é motim (agere per turbas), procedimento que a exclui da qualidade de cidadão de um Estado (KANT, 1798, p. 311, trad., p. 206).

A nota sobre a canalha visa a ilustrar, em todo o caso complementar, o que ele acabou de afirmar sobre a populaça. Ora, a populaça, escreve Kant, é o elemento selvagem no coração do povo. Segundo estas linhas, temos de um lado a nação, que se reconhece como unida em um todo civil, e do outro lado a populaça, que se excetua das leis que regem o todo. Isso significa, para exprimir a mesma ideia inversamente, que a populaça não se reconhece como pertencendo ao todo regido pelas leis civis. Nisso ela é selvagem. Diversos aspetos merecem então ser considerados:

1) existe, segundo Kant, um elemento selvagem no interior do povo. Quer dizer que, de certa forma, cada povo possui um elemento selvagem, um pouco como dizer que cada ser humano possui sua parte de animalidade. O elemento selvagem pertence tanto à noção como ao corpo do povo, corpo que simultaneamente ele integra, que ele constitui em parte e que, paradoxalmente no plano da lógica e desagradavelmente (pelo menos para Kant) no plano da materialidade, ele divide;

2) a selvajaria da populaça decorre, se não totalmente, pelo menos em uma larga medida, do fato de que ela se esquiva às regras supostamente comuns e partilhadas por todos;

3) parece certo que a classificação de uma parte do povo como selvagem e, de modo mais abstrato, a divisão do povo em dois grupos são operações que podem apenas ser realizadas pelo pensador que enuncia o seu discurso do lado da lei, do reconhecimento e da nação.

Em suma, depois de ter delimitado o povo como um todo, Kant o divide interiormente, ao traçar a fronteira que separa a civilização da selvajaria e a lei da desordem. Contudo, logo em seguida ele transforma a fronteira interior em um limite, o da cidadania, que ele faz 
acompanhar de um movimento, o da exclusão da populaça revoltada. Como afirma o texto, a reunião da populaça contrária às leis é o motim, comportamento que a exclui da qualidade de cidadã. Se antes a populaça era desclassificada no interior de um povo ao qual continuava pertencendo, agora é posta fora do espaço de uma cidadania que ela já apenas integrava parcialmente. Mais exatamente, ela se exclui pela sua ação, a qual toma a forma de um motim. É nesse ponto que Kant invoca a canalha, à qual regresso então.

De um lado a nação, do outro a populaça, eis as duas partes do mesmo povo romano. Naturalmente, a genealogia da canalha é apenas um pormenor na partilha principal enunciada por Kant. No entanto, ela introduz no quadro de análise duas condições para o bom exercício da cidadania: a ocupação do indivíduo pelos seus afazeres, e o respeito que ele manifesta pelos seus concidadãos. As pessoas ocupadas não se importunam mutuamente: é um dos preceitos que concorda com suas atividades. Em contrapartida, o monte de ociosos tem falta de ocupação e de princípios, e chama a si, por isso mesmo, as injúrias da nação. O caráter marginal dessa nota de rodapé encontra assim toda sua razão de ser: ela trata, à margem, das margens. Com uma única reserva: como mostra a cena à beira do canal, ela detecta as margens no coração da vida social e no meio do espaço da cidade.

Somos aqui confrontados com uma ambiguidade. Por um lado, a canalha é do povo, ela pertence ao povo e o integra, tal como todo o povo tem uma populaça que inversamente o constitui (como uma de suas partes) e o cinde (opondo-se à totalização do povo). Assim, não há povo empírico sem a sua canalha, sugere a Antropologia. Por outro lado, a canalha aparece de algum modo no exterior do povo, como um resto que sobra para lá do povo «propriamente dito». Ela parece ter uma importância e um estatuto ainda menores que os da populaça e encontrar-se à vista do povo não como uma das suas partes, um complemento, mas sim como um suplemento, como algo que o excede, uma espécie de excrescência.

É então que a nota do editor científico da Antropologia muda de forma surpreendente o quadro, ao vir corrigir a derivação etimológica dada por Kant. Canalha provém de cão, e a canalha do povo, 
apercebemo-nos então, são os cães do povo. Eis que a animalidade vem à tona: «a porção selvagem nesse povo» são doravante os cães que rosnam dentro da cidade. Enquanto permanecem à beira de um canal qualquer e irritam os pedestres ocupados, eles são simplesmente «a canalha». Contudo, desde que se reúnem de forma contrária à lei, eles desencadeiam um motim e desertam o espaço da cidadania. Atingimos então essa visão estonteante de uma margem que, estando todavia no interior de um todo que simultaneamente ela divide, se coloca fora do espaço cidadão, embora permanecendo dentro do povo a que continua pertencendo. Por via da ação desse elemento selvagem, a animalidade, diria Kant, exprime-se de maneira mais potente que a pura humanidade - e isso mesmo em uma constituição civil.

Com a introdução dos cães selvagens na paisagem social, toda uma conexão etimológica se insinua e transporta o pensamento: a horda de cães constitui uma matilha? Quando os cães do povo se enfurecem, desencadeiam um motim? Que diferença existe entre estas duas palavras: matilha e motim? Elas partilham a mesma origem latina, motus, o movimento. Mas representam o mesmo tipo de movimento? Em que sentido esses dois movimentos poderiam ser designados como selvagens? Eis interrogações que convidam a prosseguir a pesquisa.

$* * *$

O paradigma de canis nos devolve ao terreno da filosofia: tal como o povo, também ela tem os seus cães. É nesse contexto que o regresso de Foucault ao cinismo se torna estimulante. Ele nos lembra quão longa é a tradição do cínico como filósofo-cão. Essa tradição torna incontornável a história da conduta ética concebida em termos de escândalo e subversão, que não separa a excelência humana nem do desprezo pelas convenções, nem do desafio à opinião pública.

O cínico partilha com a canalha o desdém da civilidade. Poderíamos assim interrogar-nos em que sentido existe uma canalha da filosofia e, invertendo as palavras, também uma filosofia da canalha. Haverá uma canalha incluindo na filosofia eticamente mais rigorosa, na medida em que ela é a mais austera? Se é legítimo prolongar essa 
associação filológica, haverá então motins filosóficos, isto é, motins do pensamento e no pensamento? Que papel desempenha o filósofo que se interessa por essas relações, seja ele cínico, crítico ou genealógico?

Uma rápida leitura do retrato traçado por Foucault sobre o cinismo permite estabelecer laços inesperados com a descrição kantiana da vida na cidade, nas duas acepções dessa palavra: cidade como lugar geográfico e como estrutura política. Neste texto, almejei apenas indicar alguns pontos de cruzamento entre os dois autores e suas análises, bem como extrair delas perguntas que não perderam em nada sua atualidade. O dizer-verdadeiro opera neste quadro múltiplas funções: ponto de partida para um estudo do papel e do estatuto do cínico, ele nos convida a denunciar hoje o vocabulário daqueles que insistem em descrever a sociedade em termos da «selvajaria da canalha». O filósofo que, no sentir de uns, se dirige com ar altivo de desafio a seus concidadãos, para lançar-lhes no rosto verdades cruas, é o mesmo que, aos olhos de outros, toma o partido da plebe e acompanha seu movimento. À semelhança de Peregrino, «vagabundo ostentoso», também ele conduz a cidade que o expulsa a deixar cair sua máscara.

\section{Referências}

FOUCAULT, M. Le courage de la vérité. Le gouvernement de soi et des autres II. Cours au Collège de France (1983-1984). Editado por F. Gros et al. Paris: Gallimard; Seuil, 2009.

KANT, I. Anthropologie in pragmatischer Hinsicht [1798]. Akademie Ausgabe. Tradução. de Clélia Aparecida Martins. Antropologia de um ponto de vista pragmático. São Paulo: Iluminuras, 2006. v. 7.

Recebido: 30/09/2010

Received: 09/30/2010

Aprovado: 15/12/2010

Approved: 12/15/2010 